ENCYCLOPÉDIE Encyclopédie berbère

BERBERE

1 | 1984

1 | Abadir - Acridophagie

\title{
Système de transcription retenu
}

\section{Q OpenEdition}

1 Journals

Édition électronique

URL : http://journals.openedition.org/encyclopedieberbere/764

DOI : 10.4000/encyclopedieberbere.764

ISSN : 2262-7197

Éditeur

Peeters Publishers

\section{Édition imprimée}

Date de publication : 1 novembre 1984

Pagination : 50

ISBN : 2-85744-201-7

ISSN : 1015-7344

Référence électronique

"Système de transcription retenu », Encyclopédie berbère [En ligne], 1 | 1984, mis en ligne le 01 septembre 1989, consulté le 05 octobre 2020. URL : http://journals.openedition.org/

encyclopedieberbere/764; DOI : https://doi.org/10.4000/encyclopedieberbere.764

Ce document a été généré automatiquement le 5 octobre 2020.

(C) Tous droits réservés 


\section{Système de transcription retenu}

\section{Voyelles}

$1 \quad \mathrm{i} \mathrm{u}(=$ « ou » français $)$

a

- la voyelle « neutre » sera notée : ə

- la longueur vocalique sera notée par un tiret au-dessus de la lettre ( $\overline{\mathrm{a}}, \overline{\mathrm{u}} . .$.

- la brièveté des voyelles sera notée par la demi-lune sur la voyelle (ă, ŭ...)

- les timbres vocaliques centraux et d'aperture moyenne seront notés conformément aux usages linguistiques dominants : e (= «é »), o...

\section{Semi-voyelles}

$2 y(« j »$ de l'A.P.I., « ill » français) 


\section{Consonnes}

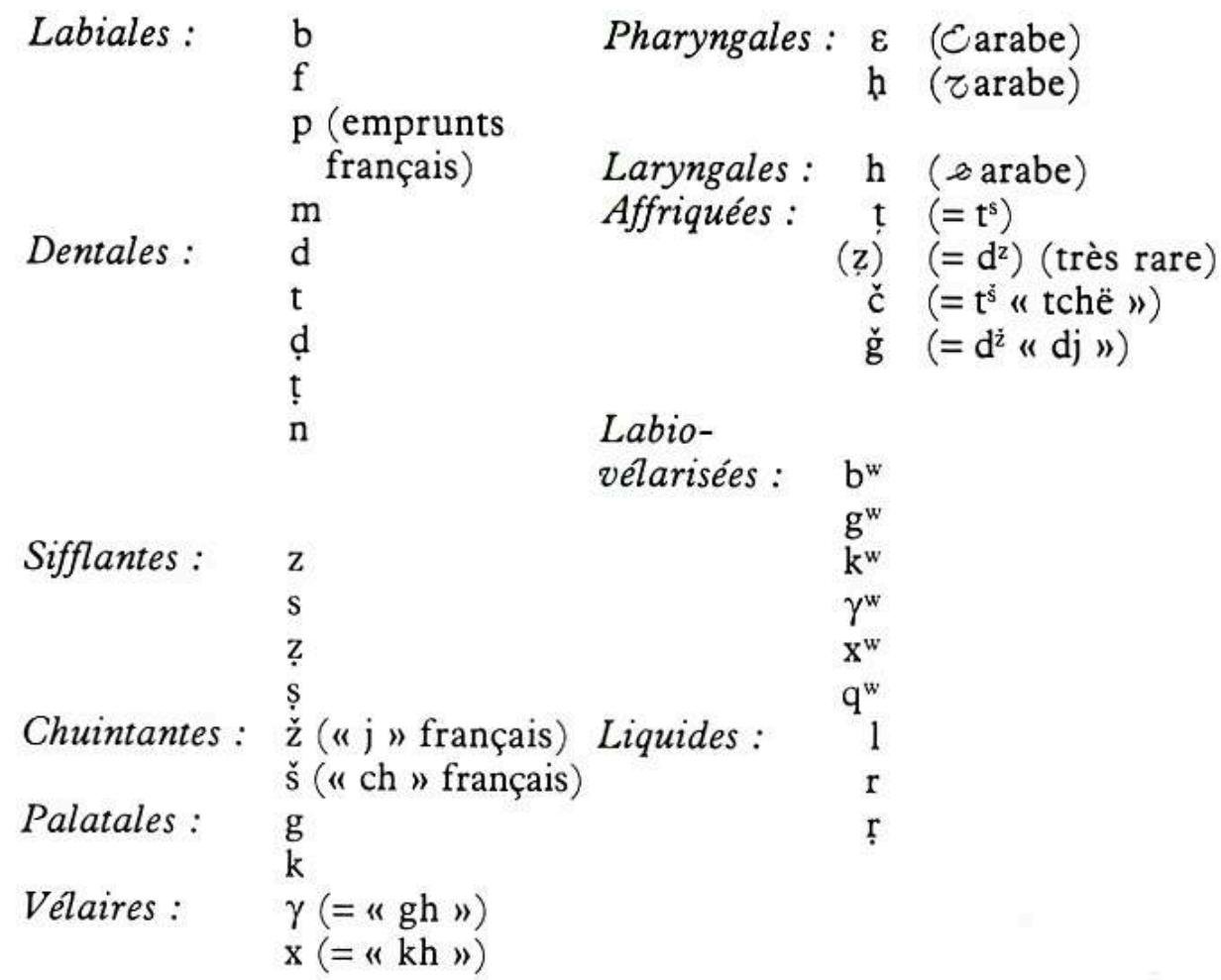

3 - la spirantisation sera, si besoin est, notée par le trait sous la lettre (t, d...)

- la pharyngalisation (emphase) sera notée par le point souscrit

- la palatalisation sera, si besoin est, notée par une apostrophe en exposant $\left(t^{\prime}, g^{\prime} . ..\right)$

- la tension (ou "gémination») consonantique sera notée par la reduplication du graphème

INDEX

Mots-clés : Transcription 